\title{
The God's Aesthetics: Material Exchanges in the Theological Construction of the Idea of Divinity in Ancient Israel
}

\author{
A estética de Deus: trocas materiais na construção \\ teológica da ideia de divindade no antigo Israel
}

\section{La estética de Dios: intercambios materiales en la construcción teológica de la idea de divinidad en el antiguo Israel}

\author{
João Batista Ribeiro Santos*
}

\begin{abstract}
The characterization of the sacred space in ancient Israel makes it possible to highlight the dimensions of the religious phenomenon, and thus identify the divinity of the place. Using the literary sources of the Hebrew Bible we will demonstrate that space was constitutive of divinity; moreover, the foundational institutions of the people are based on ritual practices. This paper presents evidence of the process of objective elaboration of the divinity - its presence considering the peculiarities of ancient Israel. Our hypothesis is that in ancient Israel, religious presentness should be researched in the context of multicultural relations - almost always conflicting - between northern Israelites and the Arameans peoples. Theoretically, Yahweh's aesthetics, originating from warrior deities, exalts the monarchical period. During this period, political conflicts have the same intensity as conceptual conflicts involving cultural agents. Thus, situated in symbolic environments, ritualistic art stands out strongly.

Keywords: Religious presentness; aesthetics of divinity; ancient Israel; Arameans; cultural memory; sacred space.

RESUMO

A caracterização do espaço sagrado no antigo Israel permite destacar as dimensões do fenômeno religioso e, assim, identificar a divindade do lugar. Usando as fontes literárias da Bíblia Hebraica demonstraremos que o espaço era constitutivo da divindade; além disso, as instituições fundamentais do povo são baseadas em práticas rituais. Este artigo apresenta evidências do processo de elaboração objetiva da divindade - sua presença - considerando as peculiaridades do antigo Israel. Nossa hipótese é que no antigo Israel, o presentismo religioso deveria ser pesquisado no contexto das relações multiculturais - quase sempre conflitantes - entre os israelitas do norte e os povos arameus. Teoricamente, a estética de Yahweh, originada de divindades guerreiras, exalta o período monárquico. Nesse período, os conflitos políticos têm a mesma intensidade que os conflitos conceituais envolvendo agentes culturais. Assim, situada em ambientes simbólicos, a arte ritualística se destaca fortemente. Palavras-chave: Presentismo religioso; estética da divindade; antigo Israel; arameus; memória cultural; espaço sagrado.
\end{abstract}




\begin{abstract}
RESUMEN
La caracterización del espacio sagrado en el antiguo Israel permite resaltar las dimensiones del fenómeno religioso, y así identificar la divinidad del lugar. Utilizando las fuentes literarias de la Biblia hebrea demostraremos que el espacio era constitutivo de la divinidad; además, las instituciones fundacionales del pueblo se basan en prácticas rituales. Este artículo presenta evidencia del proceso de elaboración objetiva de la divinidad - su presencia - considerando las peculiaridades del antiguo Israel. Nuestra hipótesis es que en el antiguo Israel, la presencia religiosa debería investigarse en el contexto de las relaciones multiculturales - casi siempre conflictivas - entre los israelitas del norte y los pueblos arameos. Teóricamente, la estética de Yahvé, originada en deidades guerreras, exalta el período monárquico. Durante este período, los conflictos políticos tienen la misma intensidad que los conflictos conceptuales que involucran a agentes culturales. Así, situado en ambientes simbólicos, destaca con fuerza el arte ritualista.

Palabras clave: Presentismo religioso; estética de la divinidad; el antiguo Israel; Arameos; memoria cultural; espacio sagrado.
\end{abstract}

\title{
Introduction: The consecration of sacred space
}

Space is constituent of divinity. Neither can be separated from the other in order to fully consecrate one's consciousness: whether that of a casual visitor, art or religion lover, or of a worshipper that dwells in there and witnesses with no incongruence whatsoever both the immateriality of the divine being and the sacrality of the symbols - stones, vessels and pots, inscriptions and tracks, trees, animals, water. So as to not degrade the temple, its administrators kept it as a "holy territory" in opposition to the external or "profane world", thus sharply characterizing the duality of the world. The process of sacralization of sanctuaries in northern Israel (Yiśrà'ét), just as in the Levant region in general, is inherited from ancient interactions between Arameans populations. The

location - a point which fixes the irruption of the divine in men - becomes a center of the world where the divine throne takes place, which will remain, during the history and the successive refections, the anchor point of the sacredness of the house of the god whatever may happen to his architectural evolution (MARGUERON, 2016, p. 17).

Hierophany works as a language mechanism, a key perspective that serves as an answer in case one calls into question the established theophorical location. In its principle lies avoiding the humanization of the cult itself, that is, all religious paraphernalia are expressed as being divinely chosen.

Among the Israelites, architecture and the paraphernalia that compose a location are closely related to living conditions; rituals were part of a nuclear family group's livelihood, specially so because

conception, birth, and child rearing had their hazards for the household and required special rituals. About a thousand roughly six-inch-tall Iron Age II statues of an abstracted female form have been unearthed, largely in domestic contexts (RUSSELL, 2016, p. 357). 
In this regard, the function of figurines, female divinities and protective objects or talismans cannot be summed as being just the crystallization of enactments; even in domestic environments, cultic actions extrapolated the small group's therapeutic usages. It would not be too much to note how close gravesites are to residential locations - a factor that determinant not only of location, but also belonging. They were socially prescribed.

Indeed, in a broad, critical theological evaluation of Israelite origins, the priesthood of ancient Judaism stuck to contemporaneous cults amidst the remembrance of ancient rituals - among them, the feasts dedicated to the dead. ${ }^{1}$ Even though corpses were thought to be sources of contamination, many families resisted detaching from them. The establishment of a large family or village turns a location into a bämāh, a natural or artificial elevation with a platform built onto it, where a shrine or open air altar is erected.

Indeed, popular festivals - to employ contemporary terminology - were so multi religious that it goes beyond the reasonability of our sources any postulates that leads us to affirm, as Stephen C. Russell did, that worship in these bamôt ("high places") during monarchy were "legitimate expression of religious devotion to Yahweh" (RUSSELL, 2016, p. 363), especially when the fictional narrative in 1 Samuel 9 is used an example - a multi-layered literary construct. However, shrines, holy places or temples, especially those founded by Israelite identity, such as Betel (Bêt-'èt) and Dan (Dàn), are place where pilgrims structure their cosmological ideas. Therefore, this alone makes it impossible for one single divinity to prevail. In those times and places Yahweh was not yet 'ehâad ("one", "unique"). ${ }^{2}$

The square-shaped temples found in Israelite and Syrian cities reached Ma-ri-a-nu-um in the third millennium. The reproduction of this model shows its essentiality in the landscaping of those cities. In Jean-Claude Margueron's opinion, "the Syro-Mesopotamian city is a founded organization, an organized environment and an entirely artificial creation" (MARGUERON, 2016, p. 24 ), with its social fabric woven around the sacred. We can place the cities in Northern Israel within this framing, especially Samaria (Sämirina).

The construction of a new capital in the highlands instead of a valley is better explained as an architectural symbol of monarchic religion that predates Jerusalem, and not only as just a barrier against harassment in a region that has been historically strategic for imperialistic expansion. So, in

According to Psalm 106: 28: wayyō'kalu zibhê mêtîm ("And they ate the sacrifices of the dead"). See also: RUSSELL, 2016; SOUTHWOOD, 2016.

2 Israelites, or, in fact, Judahites were not yet under Neo-Babilonian Empire domination during the $6^{\text {th }}$ century BCE; for instance, Isaiah chapters 40-55. 
a way, the customs of the first urban civilizations in the Ancient Near East are maintained - urban infrastructure, hydrology and frontiers are in relation to a specific deity. This implies a form of elective patronage of a city by a deity, but whose founding apparition corresponds to a mythological tradition based in the telling of a story situated in the past.

Oftentimes conflict between cities that share the same lineage also involves the leadership of the pantheon; it is part of the nature of those cities. All types of foundational acts - whether cities, shrines, monuments, altars, cults, monarchies - are engendered through rituals that sacrifice vegetables, which include the preparation of food, or even of animals incorporated into new social structures and events that implicate the deity. However, Ioanna Patera (2016, p. 67) states that whatever the rite - whether consecration or reestablishment of sacrality - is invested with not so much with separating sacred from profane than it is with a legitimate claim for land. It seems that this relation is present both in the foundation of Samaria by Omri and in the foundation of the royal temple by his son Ahab ('Ah'a $b$ ). The religious-political context involving both cities in Deuteronomistic History formulates the elevation of Yahweh beyond Israelite borders,

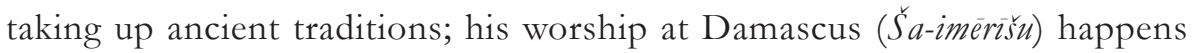
in domestic environments by patriarchal designation, employing him almost simultaneously as a backer in the wars for power that occurred between those two small kingdoms. On the other hand, forensic indictments of $\mathrm{Ahab}^{3}$ are sustained because he built a "damascene" altar in his capital.

The kind of worship practiced in that altar remains unknown whether it was Assyrian, Aramean or Phoenician. What seems beyond doubt, though, is that this worship was not Yahwist. Its motivations were probably the religious interactions in Northern Israel that already had structured priesthood, the military pacts in the region in face of Assyrian interests in the Levant, and the assimilation of the deities Baal $\left(B a^{\prime} a l\right)$ and Asherah ('Ášerāh). As Nili Wazana (2016, p. 380-381 and 383-385) notes, Ahab does not introduce new elements into the temple. The criticism in the Hebrew narrative lies in the fact that this element is identified as coming from Damascus, disregarding the supra-regional conjuncture. The reestablishment of divinities in the royal pantheon occurs not only in Assyria ( $A \stackrel{s}{s}$ sur $)$ but also in Babylon (Bäb-ilì) with the appointment of priesthood by the king Nabû-apla-iddina (888-855) - Shamash (Šamaś) in Sippar and other divinities in ancient temple-cities, whose repopulation is legitimized by AMAR.UTU ( ${ }^{\mathrm{d} M a r d u k) .}$

For an interpretation of this, we suggest Mordechai Cogan and Hayim Tadmor (1988, p. 193). 
With the erection of an altar or the reconstruction of a shrine in Samaria, Ahab becomes part of this process that forms the religious field in Northern Israel. Historiographers from Jersualem show they understood or at least did not reject outright the Israelite political traditions when they connected the priest Uriah ('Úriyyäh), from Ahaz (2 Kings 16: 10b-11), and Bezaleel (Bașalo'êl) son of Uri ('Ûrî) (or is it 'Ûriyyahb?), a leader in the construction of the mythic religious field (Exodus 31: 1-11; 35: 30) whose literary elements were elaborated during de Persian Achaemenid period, between the sixth and fourth centuries BCE.

Literary evidence also establishes a connection of locations, Damascusmountain-Samaria-Jerusalem. Deuteronomistic criticism, stemming from a particular point of view, points to the model of cult practiced in Samaria by projecting a particular perspective the translation of the deities Haddu-Ba'lu-’ Ǎšerāh-Yahweh-Hădad-rimmôn. By the way, these criticisms are retrospections made by different redactors that had no information whatsoever - neither from sketches of the altar nor the date of its construction: ${ }^{4}$

1 Kings 16: 32 - And he raised up [= 'Ah' $\bar{a} b]$ altar to $B \bar{a}^{-} a l$ from the house of $B a^{\prime} a l$ [labā'al bêt habba'al] which he built in Šōmorôn.

2 Kings 16 - v. 10 And it was king 'Ahāaz to meet Tiglat Pila'eser, king of Ašsur, [in] Dûmméseq, and saw the altar that [was] in Dammáseq; and he sent the king 'Ahāz to 'Uriyyahh, the altar drawing and his drawing for all his deed.

v. 11 And he built 'Ûriyyäh, the priest, the altar, according to all that sent the king 'Ahāa, of Dammeśeq, so he did 'Ûriyyāh, the priest, until the king 'Aḥāz of Dammäśeq went. v. 12 And the king went from Dammeśeq, and the king saw the altar, and the king came to the altar, and served [wayya'al] on it.

Being an architectural model, Damascus provided sketches for the main altars on sacred spaces in the capitals of the two small kingdoms between the $9^{\text {th }}$ and $8^{\text {th }}$ centuries BCE that shared the same 'br origins. Cultural exchanges oftentimes respect no boundaries: it is possible that Yahweh was a major deity in the Hamath (Hamāt) pantheon. Cuneiform sources dated from 738 BCE, along with theophoric elements in the annals of Tiglath-Pileser III offer evidence to the appearance of Yahu in that city. There is also mention of a Syrian governor, Yau-bi'di (İlu-bi'di). In addition to that, in direct relation to the importance of Damascus had, many material sources bear witness to

42 Kings 16: 1-4; see also 2 Kings 10: 18-21 and 21: 3-5. Important information for narratives of Hebrew Bible texts: The translations are made by the author from the Biblia Hebraica Sttutgartensia (ELLIGER; RUDOLPH, 1997). 
the complete mutation of deities involving Yahweh and Haddu in the cities of Hamat and Samaria (WAZANA, 2016, p. 393-394).

It is a political fact that the altar or temple in Samaria was commissioned by king Ahab. Nevertheless, the Israelite historiographer keeps it as just a religious fact. The same holds true for the political significance of the temple complexes at Siloh (Šilöh), ${ }^{5}$ Betel, ${ }^{6}$ Dan, Hazor (Hașōr), Megiddo (Magiddô), and Lagish (Läkî́s). They were active since the tenth century BCE, and cults in the bamôt happened outside the cities, in their outskirts or even within their walls. The scribes and ethnographers that wrote the Baal cycle didn't grasp this peculiar perception. This is why the lexicon related to the reconstruction of the Baal ( ${ }^{\mathrm{d} I S ̌ K} K \mathrm{R}$ ) temple in the year $1250 \mathrm{BCE}$ in Ugarit (Ú-ga-ri-it) presents the architecture of a house or palace, not of a temple in which a deity dwelt. This conveys simultaneously the building of a palace and the production of a divine presence amidst the City State's inhabitants in tune with the king.

In Carole Roche-Hawley's opinion (ROCHE-HAWLEY, 2016, p. 89):

The palace is the very emblem of royal power "the seat of sovereignty" and the description of the construction of an important building of this type is part of a propaganda aimed at establishing the sovereignty of the king in the case of TukultiNinurta or that god Ba'lu in the case of the Ugaritic myth.

One can find similar government propaganda in the Moabite King Mesha (Merá) stele, and probably is part of the commission King Ahaz made to the priest Uriah. Roche-Hawley informs us that many archaeological studies show that many important buildings in Ugarit that date to the time of the Temple's dedication give witness to contact between Ugaritic and Assyrian architects. This exchange of technologies were started by other inhabitants of that region during the $3^{\text {rd }}$ millennium BCE. In Ugarit, the King hired Egyptian craftsmen that employed the model of temple architecture they were used to; in Northern Israel, the inspiration was Damascus; but in light of the preeminence of Aleppo ( $\mathrm{Ha}-\mathrm{la}-\mathrm{ab})$ and Ugarit religious field, the altar in Samaria should be considered within this context of the assimilation of the cultures of those cities that integrate different kinds of deities and, therefore, of large architectural buildings.

Judges 18: 31; 1 Samuel 1: 3, 24; 3: 23; 4: 3-4; Jeremiah 7: 12, 14; 26: 6, 9.

6 Genesis 12: 8; 28: 8-20; 35: 6-7, 9-15; Judges 21: 2-3; 1 Samuel 7: 15; 10: 3; 1 Kings 12: 30-33; 13; 17: 27-28; Hosea 4: 15; 5: 8; 10: 5-8 (Bêt 'Āwen); Amos 4: 4; 5: 5; 7: 13. 


\section{The presentness of the religious field}

To assess social trends in historical terms, one needs only to highlight that Northern Israel constitutes a socio-ethnical entity that presents itself through the figure of its King and has its cultural diversity threatened by the imposition of Yahweh veneration. ${ }^{7}$ While on the one hand cult centralization had little relevance, on the other hand palace international relations through a system of royal marriages, buildings and defenses provide a much more relevant counterpart to that. The same can be said about Judah (Yahûdāh): in concrete life, confessing a deity stimulated symbolic exchanges.

Religion constitutes a society's most complex domain. It is the maintainer of a structure made up of a multitude of different pantheons that differ in its details. In Ancient Israel, some pantheons of Canaanite origins excluded from their iconography the presence of Yahweh, and of this "agrarian and urban religiosity of the Canaanite environment is added to the religiosity of groups of shepherds, of varying typology, and based on different assumptions", because the deity

\footnotetext{
"The chosen divinity, Yahweh, was unlikely to be new in the region, but certainly it was not one of the greatest and most qualified divinities, more therefore linked to a particular environment or to an already rooted mythological and cultural heritage" (LIVERANI, 2009, p. 684).
}

However, even if relative, changes during the monarchical period associated Yahweh to El ('El), "god of fathers", in the animal fertility tradition. This turned him into a deity associated to other deities, but also paradoxically increased his prestige as deities tied to rural environments were progressively marginalized.

But marginality does not equal banishment! Canaanite religiosity prevailed in the valleys of Northern Israel, including the diversity of SyroMesopotamian deities that appear in teophoric names some locations were given, even when a mutation occurs in their composition. We have noticed many cultural interactions and material connections in Northern Syria; however, Amihai Mazar (2007, p. 175) has been presenting Phoenicia as strongly influential in the formation of Israelite religious spirit; he attributes the prior representation of Yahweh's together with a consort to a Canaanite pantheon, where $\mathrm{El}$ is the major deity and Asherah his consort. ${ }^{8}$ This only

\footnotetext{
Different from Rainer Kessler (2010, p. 117).

8 This is recurring throughout dozens of Levantine and Mesopotamian pantheons; see Olmo Lete (1988) and Bottéro (2001).
} 
confirms the multifaceted character of religious phenomenon in Northern Israel - while at the same time lifts Yahweh to the top of the pantheon. In this setting, offerings to the temples and shrines, such as livestock, honey, oil, fruit and cereal, processed foodstuff such as flour, butter and cheese, products cooked or baked in the oven, besides precious metal and clay objects among others (BECKMAN, 2007, p. 371-72), could be exchanged for local currency (Hebrew: kesep) - boosting regional trade involving families and the royal temple and also resale by the priesthood. ${ }^{9}$ Therefore, adoption of these measures helped integrate Israel once for all into the commercial system along with its currency, that were the main social status markers in the Ancient Near East.

Western Semitic religions have existed since Late Bronze Age, and as the Israelites advanced in their political structure they integrated into Yahweh elements of the God of the storm; this process of incorporation was concluded during Persian colonial times (NIEHR, 2010, p. 30). ${ }^{10}$ But well before that, Yahweh starts being represented by taurine icons and by the gods Baal and Haddu in the ancient temples at Betel and Tel Dan, just like what happens to Ištar. The separation of Yahweh from those deities suggests the existence of a political boundary. The first glimpses of a particular culture in Ancient Israel are to be found in the struggles for the liberation of the people, whether from the Philistines, or the revolts against physical subjection or the high taxation of production, constituting new leaders that stood for lower tributes.

These popular revolts lead to the rise of King Omri, whom built a new capital for Israel, moving power from Tirzah (Tirșāh) to Samaria. Not dividing his kingdom into provinces played to his advantage, despite the militarization of small regions. This makes sense, because political divisions would strengthen cultural rifts and would allow for easier tax collection: there are some that affirm the existence of a "more Israelite" party in the outskirts of Northen Israel, and a "more Canaanite" party in Samaria and the territories that were later named as the Manasseh (Mənaššeh) settlements. ${ }^{11}$

\footnotetext{
9 "To manage cults, economy and production of knowledge, the sanctuary was organized according to structures sometimes difficult to find", according to Philippe Clancier (2014, p. 438). But nonetheless documented in 1st millenium Babylon. Because they did not keep up with regional political and economical advances, these experiences will only take place in the Jerusalem temple during Hezekiah's reign (end of $8^{\text {th }}$ century BCE-beginning of $7^{\text {th }}$ century BCE) and, systematically, during the second temple period.

10 E.g. Judges 5: 4-5; Psalm 18: 8-16 = 22: 8-16; 29; 65: 10-14; 104; Jeremiah 10: $13=$ 51: 16; 14: 22; 31: 12; Hosea 2: 10; Habakkuk 3: 3; Haggai 1: 2-12; 2: 15-19; Zechariah 8: 9-12; 10.1.

11 This is how Henri Cazelles (1986, p. 163).
} 
Monuments dedicated to the God of Exodus, ${ }^{12}$ placed in the central temples of Betel and Dan, represent the founding Israelite traditions. There are also temples in Shechem ( $\breve{S}$ əkem), Gilead (Gila ' $\bar{a} d)$ and Samaria that had 'Ël-Yahweh cults. There are many evidences to that: the epithet 'glyw, attributed to Yahweh in a ostracon from Samaria ("Yhwh is a calf"). Also the epithets par, šór, 'àbîr and $r o$ 'èm applied to Yahweh, as well as 'ābîr ya'ăqōob/

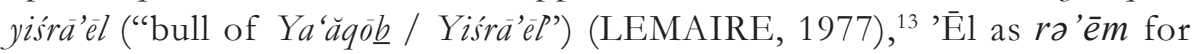
yiśrä'el ("bison of Yiśrä'êl'). In the Baal cycle, "the benign 'Ë' is "the bull 'EP' (OLMO LETE, 1988, p. 45). ${ }^{14}$ These icons were publicly shown during festivals, and even miracles were believed to occur by merely touching them. Scholars have been distinguishing the bovine images related to gods in the Ancient Near East, especially in Mesopotamia and Anatolia. Regarding all of this, Jeremy M. Hutton offers this conclusion (HUTTON, 2018, p. 159):

First, the term need not have described merely the diminutive stature of the images themselves, but may have comprised a deprecating swipe at the representation's supposed power and vigour. Second, the description was possibly an intentionally belittling transfer of the deity's assumed identity Yahweh-El to the more blasphemous Baal-Hadad. In this understanding, the historical purpose of the imagery would have been to represent Yahweh in this El-type capacity as a bull, but the Deuteronomistic commentators, unable to make the explicate charge that Jeroboam had instituted Baalism in Israel, nonetheless sought to implicate that "renegade" king through a campaign of subtle innuendo.

Besides the impossibility to properly substantiate on historical grounds all this criticism against the Israelite dissident, in the version of the Exodus from Egito (Mi-is-ri) preserved by Northern Israel Yahweh is represented by a calf:

Exodus $32-{ }^{v .3}$ And they plucked out all the people with the golden ornaments ('et-nizmêe hazzāhäb), which [were] in their ears, and brought them to 'Ahărōn.

v. 4 And he took their hand and fashioned it with the chisel (wayyāṣar 'ōtô baheret), and made him a metal calf ('égel massēkeäh). And they said: "These thy 'êlōhîm, Yiśrä'èl, who brought you up from the land of Mișrāyim.

v. 5 And saw 'Abărōn, and built an altar in front of him, and proclaimed 'Abărōn, and said: "Feast (hag) to Yhwh tomorrow".

As traditions were received, we notice some connection of Yahweh to metallurgy, always in redactional layers later than the Babylonian Exile.

\footnotetext{
12 See 1 Kings 12: 26-33.

13 See Genesis 49: 24; Isaiah 1: 24; 49: 26; 60: 16. Herbert Niehr (2010, p. 30) states that Yahweh was represented by a Bull in the shrines at Betel and Dan.

14 E.g. Numbers 23: 22; 24: 8;
} 
Nissim Amzallag (2009, p. 387-404) wrote an article filled with quotes from the Hebrew Bible, where he tries to substantiate the theory that Yahweh was a Canaanite god of metallurgy by the plausible means of compared biblical research. His framing for those quotes consists in (1) the fact that Ugaritic texts have 240 unnamed gods, so Yahweh could be one of them; (2) the archeological finds that shown that metallurgical production occurred in Arabah, where "from 150.000 to 200.000 tons of slag resulting from copper metallurgy dating from the Chalcolithic Age up to the Iron Age" were found; therefore (3) Yahweh relates to copper ${ }^{15}$ and (4) the relation to the bronze serpent. ${ }^{16}$ To conclude his argument, Amzallag (2009, p. 403) recognizes that he presents many parallel narratives that can persuade us only to enroll Yahweh among many other gods of mettalurgy known in Antiquity - perhaps a Edomite god - and, unfortunately, he says he does not know Yahweh's origins. Therefore, let us stick to the image of the Samaria bull.

In the legends on the origins of the monarchy, God ('Élöhim) is represented by calves:

1 Kings 12: 28 - And the king let himself be counseled, and made two golden calves ('egale $z \bar{a} h \bar{a} b$ ), and said unto them: "It is very much for you to come up from Yarûšălam, behold your 'êlōhim ('êlōheykâa), Yiśrä'èl, who brought you up from the land of Mișrāyim.

In the Deuteronomistic narrative about the "blessing of Moses (Mōšeh)", inserted into Deuteronomy during the $4^{\text {th }}$ century BCE, the patriarch Joseph (Yôsepp) is hailed in comparison to a wild bull, a buffalo. It presupposes referring geographically to Northern Israel as Yahweh's firstborn:

Deuteronomy 33: 17 - His firstborn of his bull (bakôr šôrô), the ornament for him, and wild ox horns (waqaranê ra'èm), his horns, in them peoples shall scorn (yənaggaḥ) together ends of earth; and they myriad 'Eprayim, and they thousands of Monaššeh.

The Exodus tradition may have been invented to organize resistance to Egypt's protectorate, during the period the southern Levant was occupied by Pharaoh Shoshenq I (̌̌šnq; Šišaq, c. 945-924). In this setting where iconic cults were practiced and its images were widespread, Yahweh began to be worshipped in the figure of a bull. In this context, the struggles for liberation from slaveholding regimes in the traditions of the patriarch Jacob ( $Y a \cdot a ̆ q o ̄ b)$

15 Bases that were established by writers that had apocaliptical influences, such as Ezekiel and Zechariah.

16 The appearance of the serpent as a deity among other people, such as Sumerians and Greeks, also serve to support his claims. 
were still relevant. ${ }^{17}$ On the other hand, archeological digs conducted by Rami Arav found a shrine with a stele in honor of the Aramean "Moon God" in Harran (Harrān) (DEVER, 2010, p. 526). Maybe the paradox lies in the fact that priesthood gained autonomy, because distinctive cultural politics gains momentum in temples with iconic cults, as it is usually practiced. This transition from local autochtony to regional intergration, from family or clan activities to cultural connections reaches its peak in the $9^{\text {th }}$ century BCE, with the temples and, undoubtedly, with the foundation of a new capital, which is ignored by the so-called Deuteronomistic History: ${ }^{18}$

Junto a las nuevas formulaciones sincretísticas del yahvismo en el culto oficial de la época monárquica - con amplitud considerable en Jerusalén, y más modestamente en Betel -, las tramas internacionales y la apertura cultural que se produjo con la creación del Estado israelita llevaron a un sincretismo diplomático, es decir, a la introducción de cultos a los dioses de los países vecinos con los que la casa real de Israel mantenía relaciones políticas (ALBERTZ, 1999, p. 274).

We have verified that cultural boundaries extrapolated the realities experienced by lineage alone. As Paulo Nogueira (2012, p. 22) states it, cultural boundaries are "a kind of film that filters the exterior and elaborates it, adapting it". Magical, cosmological and ecstatic religious practices, even the much despised fortunetelling were understood and even took on - even if under protests - into their traditions. ${ }^{19}$ One need only to notice the free worship of many deities, as well as their many artistic depictions, that are attested at least until the period of the presumed great reformation led by King Josiah (Yóósiyyāhûu) between 640 and 609 BCE: Asherah ('Ašérāh) and Baal together with Yahweh in Jerusalem; Ataroth/ Ashtoret ('Ašstöret/'Aštàrōt) (Phenician-Canaanite), Astarte ('Aštar) (Ugarit), ${ }^{20}$

17 In the history of the Patriarchs, the Y cycle in Genesis *25-35 mentions only northern locations: Betel

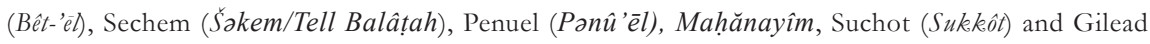
(Gila 'âd); connected to Laban (Läbän), Harran (Harrān) to the north of Mesopotamia is mentioned three times: Genesis 27: 43; 28: 10; 29: 4, besides the Exodus - Moses narratives and the traditions of the Judges.

18 The Deuteronomistic Histroriography sums up the importance of Samaria (Šōmorôn/Sämirina) in a single verse (1 Kings 16: 24) - a strategic arrangement that allows control of both the plateau and also the Jezreel (Yizra ' $e$ ' $l$ ) and Šaron valley plains. It interprets the northern Kingdom's economic power in light of religious polemics. Indeed, acceptance of Yahweh worship is the key aspect Deuteronomistic History evaluates a king for - disregarding royal achievements.

19 Regarding the dichotomy between "official religion" versus "popular religion", Albertz acknowledges later on that this is Christian religion construct, e.g. ALBERTZ, 2012, p. 50. See also MEYERS, 2018, p. 118-34.

20 Thomas Römer (2017a, p. 114) affirms that Ugarit would be a male deity, but, based on the Moab document, it would be a female deity. 
Milcom (Milkōn) (Ammonite), Chemosh (Kamāss) (Moabite), maleket hašămayim or the Assyrian goddess "Queen of the Skies" (DEVER, 2010), ${ }^{21}$ Deber and Rešep ( $s b$ ' $i$, in the same conception of "Yahweh of the hosts") or the gods from Ugarit "Pestilence" e "Epidemics", ${ }^{22}$ besides the Sumerian-Babylonian Tammū $z^{23}$ and the Canaanite god Mekal - a stele in homage to this god was found in Bet-shean (Bêt-Šð'ān). There is even El's court or astral family serving Yahweh, şabā' haššămayim (Akkadian: puhur ilāni), ${ }^{24}$ and, as bənê 'elōbim, happy with the creation of the world. ${ }^{25}$

Regarding Chemosh, god from Moab (Mốâb), the monumental king Mesha stele confronts him to Yahweh, hailing him for seizing the cultic paraphernalia ( $k l y=$ "vessels", "figurines") and taking it to Madaba. On that, we must highlight that in the Mesha document the existence of a shrine to Yahweh in the city of Nebo (Nabô/Nībū that was destroyed by said king, and also the god Dod $(D \bar{o} d)$, the "Well Beloved", worshipped in Ataroth. ${ }^{26}$ As we have seen, this correlation that extrapolates geographical boundaries functions legally for appropriations, employing myths from Anatolia, Phoenicia, Mesopotamia and Syria (Süriya $)$. For instance, in Ugarit there is direct relation from the major gods there to the system from Anatolia and the High Eufrates: Īlu e Haddu $\left({ }^{\mathrm{d}} \mathrm{IM}\right)=$ Ba'al, 'Anat, Šapšu, Atirat.

The expansion of pantheons beyond their original territories allows us to trace the changes an image underwent. This is evidenced by the expression 'str kms in the $17^{\text {th }}$ line of the king Mesha monument ("for I have consecrated 'Aštar-Kamāšs" [ky l'šstr kmš hrmt]). The goddess Astarte ('ttr, aš-ta-ru, 'Attaru) would have connections to the god Chemosh beyond the form of worship or belonging to the same temple because "In an $8^{\text {th }}$ century tomb before ours, which was discovered in Amman, we found a clay figurine with a female body and a bearded face. This hybrid statuette was interpreted to represent a hermaphrodite deity identified with 'AshtarKemosh" (RÖMER, 2017b, p. 387).

This finding confirms the eventual hybridization revealed by the $9^{\text {th }}$ century BCE Moabite monument, further corroborated by the dual-gendered composite name. Later, we will also find a similar relation involving Anat

21 See also 1 Kings 11: 7; Jeremiah 7: 18; 44: 19.

22 See Habakkuk 3: 5.

23 See Ezekiel 8: 14.

24 See 1 Kings 22: 19.

25 See Job 38: 6-7.

26 Besides alluding the Moabite document, understands that the archaic quote in Amos 8: 14 (dodeka, "your well beloved") allows for this version, that is further supported by the Septuagint - that translates "Dôd” as "Theós". See RÖMER, 2017a, p. 114-15. 
and Yahweh, according to documents from Elephantine. If in Amman bears witness to the duplicity of Astarte's depiction, in Ugarit the conservation of the name leaves as a counterpart a biological change - she is attested as "ttr'um (“Aštar is mother"), but also appears as a male deity. Where we find no hybridism, the relation occurs by competences and attributes; Ishtar ('Istar) or Inanna, the Mesopotamian Astarte, is venerated as a goddess of love and war - that is, she combines attributes that are respectively female and male. This is why Römer (2017b, p. 391) proposes we understand the Astarte of Chemosh mentioned in the Mesha monument as a goddess venerated hrm like the Mesopotamian Ishtar, a warrior goddess, due to the difficulty of designating her as just a consort.

We have seen many aspects of translations, hybridizations and mutations undergone by deities. As an unveiling of the process of civilizatory domination, we highlight that the deity Asherah was "first attested in Mesopotamia, at the time of Hamurabi $\left(18^{\text {th }}\right.$ century before our era). In Akkadian and Hittite, she appears as Ašratu(m), Aširatu and Aširtu; in Mesopotamia it is also attested in three ritual texts of the Seleucid epoch" (2017a, p. 158). Assyrian steles show that between the $8^{\text {th }}$ and $7^{\text {th }}$ centuries BCE kings would refer to supernatural occurrences as ways of gaining knowledge, and that the "Babylonian ruler Nabonidus (sixth century BCE) also claimed privileged access to the gods through dreams" (FOSTER, 2007, p. 262). Therefore, there was even the deity Sin, Akkadian moon god whose temple was in Ur, hailed as the one who lighted up the skies and the world underneath it, as well as supporting it from end to end. Benjamin R. Foster highlights that those revelations were communicated via doctrinal or political corpus that contained commentaries about royal projects. This pluri-religious Assyrian setting has led S. David Sperling (2007, p. 433) to challenge Simo Parpola's affirmation "that underneath the apparent polytheism of Assyrian religion was a unifying monotheistic notion" and not current practice.

The hegemony of Mesopotamian languages during Iron Age II can not be forgotten, but they nonetheless confronted the prevailing scribal culture in Mesopotamia; close to the Mediterranean, Ugarit and Israel developed their own literature, thus showing they possessed people knowledgeable in their own language. Ugarit shows remarkable literary independence from omens literature, medical texts and lexical lists produced in Mesopotamia. In dialogue with Seth Sanders, Mark Smith (2010, p. 180-181) highlights that, within the context of international Akkadian hegemony, particularly that of the scribal culture of Mesopotamia, Ugarit and Israel produced literary works in their own language. That is to say they invented new forms and genres to 
record their realities. Notwithstanding the presence of classical compositions founded in the traditions of Atrahasis, Gilgamesh, etc., Ugaritic scribes carried out a veritable translation of Mesopotamian literature. With some differences, Israelite scribes "shows not only the development of an indigenous literary corpus in the local language of Hebrew, but also translatability of literary works or motifs into this vernacular" (SMITH, 2010, p. 182). Evidently, linguistic novelties are based in material from Mesopotamia.

In the representation of deities, however, Ugarit and Israel present some peculiarities. One must observe the ways Israelites related to their deity:

For ancient Israel there is a translation of literature, but it does not show translatability of divinity. Instead, there is absorption of divinity (Yahweh as the repository of all positive divine character) as well as counter-construction (Yahweh powerful beyond the empire gods who are in fact powerless). In any case, there is no translation of deity in this literature (SMITH, 2010, p. 183).

There was still no translation of deities, but correspondences between the religious fields already existed. This linguistic setting, which also comprises material representations, will be rejected after the Babylonian Exile, when literary utopism will seize the place occupied by both prophecies of doom and the priesthood and undertake the removal of religious images in the worship of Yahweh - imposing limits to social relations. Now that we mentioned this later development, the political stability brought about by King Omri's dynasty - which counted four kings in its forty years span - enabled the North to dialogue with neighboring peoples. The semitic inscriptions in the Assyrian Annals such as Karkar's mention the great kings Omri and Ahab. The Black Obelisk mentions the humbling pact of Jehu (Yéb̂̀') (842-814 BCE) with Shalmaneser III (Šulmānu-ašaridu) (SANTOS, 2014).

Spread from Samaria, the persistent differences in practice are summed up in the biblical narratives involving Yahweh and Baal, whose agents come from all social strata - common people and also särîsim, within their social boundaries. Therefore, formal dualism in religion is just a cover-up for dozens of deities. Along with the major Canaanite ${ }^{27}$ deity El stood his son, Baal, the young god of agrarian fertility that had a shrine in har Karmel (Mount Carmel) and another one that was very sought after, built by Ahab in the capital city of Samaria. The female deities Ataroth/Ashtoret and Asherah retained their prestige as the most popular goddesses since the Bronze Age. There was

27 Starting in Iron II, "Canaanite" is an ethnical designation; however, we should not disregard reading the Hebrew Bible from a sociological or religious connotation; in terms of population, various social entities. 
also the Tyrian god Milqart and the god Chemosh. A certain Damascene king called Bar-Hadad I is mentioned in an inscription on a religious figurine found in Aleppo that was dedicated to the god Baal of Tyre $(S \bar{u} r)$, that is, dedicated to Milqart (LIVERANI, 2009, p. 575-576 and 719-720) - one of the many extant examples of this supra-regional cultural connection. Yahweh had his royal shrine in Betel and others in Siloh, Gilgal (Gilgāt) and Nebo, with their own priesthood, prophets and iconic rituals just like in bämôt. As stated, the "Yahweh only" movement was part of this setting.

With no disregard to all the local peculiarities researched by Mario Liverani, we could in part challenge Rainer Albertz (1999, p. 280) on his claim that Northern Israel adopted a religious policy to its utmost consequences, and that it also had repercussions in the Southern Kingdom - also that the Northern Kingdom's religion was just a "polytheistic" version of the cult of Yahweh. There are many Hebrew narratives where Yahweh is represented as a god that fertilizes, provides rainfall and sun, makes seeds sprout, children be born, etc., "The broad coincidence of attributes, epithets, and names between Yahweh and El makes one think that Yahweh emerged as an assignment of El, who separated the ancient god when the worship of Israel departed from its polytheistic outline" (TERRA, 2015, p. 163; cf. SILVA, 2006).

Some ancient Israelite traditions already placed Yahweh far from the Jordan Valley, the region designated in the Hebrew Bible as the "promised

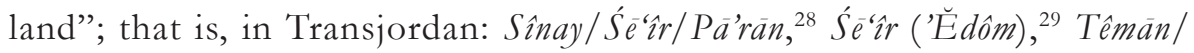
Pärān (Mốäb), ${ }^{30}$ Sinay. ${ }^{31}$ Such incorporations occur in the construction of the Israelite culture, ${ }^{32}$ but our research has been placing its geographical origins in the Northern Levant. In this cultural archaeology, we should observe that it is not reasonable to oppose the fact that economy is perceived as a benevolent action by the deity, because what is at stake is the divinity's saving action that provides well being. So it is fitting to ask ourselves about the Israelite's worldview at that time. According to João E. N. Terra, Yahweh is

28 See Deuteronomy 33: 2.

29 See Judges 5: 4.

30 See Habakkuk 3: 3.

31 See Psalm 68: 8-17. A region whose location is debated.

32 Thomas Römer, based specifically on Hebrew Bible texts and an $8^{\text {th }}$ century inscription carved in Kuntillet "Ağrūd, proposes the origin of the deity Yahweh in the south of the Levant, the "Southern Yahweh". In our view, with literary layers of the book of Exodus presented as a basis, all the postulate with matrix emphasis in Egypt, so conjectural, reverberates the commonplace of biblical paraphrase. Römer's sources are very late, plus the worship of Yahweh in the desert - "a violent god, and the god of the Hebrews" or "a terrible warrior god" - is a long-term collaborative elaboration of the cults at Kuntillet 'Ağrūd and the traditions of the god Haddu or other so many protective male and female deities not uniquely named by the Jews. 
closely linked to the political institution, that is, to the kingdom of Judah Israel and the events of the Davidic dynasty. There is also a vast reactionary movement, animated by the prophets who react to free the Javistic faith from its limitations, to highlight the moral demands of Javism and to reinforce the monolatric character until a monotheism worthy of the name is achieved (TERRA, 2015, p. 295, grifo do autor).

This quick confluence of interests and practices was pushed forward due to contacts with the Canaanites, that were more technologically advanced, and by the peril of extinction yahwism faced. This is consistent with the fact that a large part of the Hebrew's Bible redactional groups shows "a polytheistic language to speak of God” (TERRA, 2015, p. 328). Römer (2017a, p. 44-45) argues against some documents from Ugarit and Mari (Ma-ri-a-nu-um) in which "Yw" and "Yahwi-ilum" are presumably mentioned, disqualifying them as obscure in one case, and just a "verbal form" in another - so both are very far from Yahweh as a deity. Of significance, we have just the account of an Ugaritic banquet presided by El where $\mathrm{Yw}$ is mentioned as his son, in parallel to Deuteronomy 32: 8; there, Yahweh is one of El's sons, and his inheritance is Jacob/Israel. However, it isn't unheard of that major deities in their respective pantheons and also kings received patriarchal deference - Asherah had seventy children (OLMO LETE, 1988, p. 89), just like the Israelite king Ahab. All of this, because they are ideals, also correspond to the real: social life and the sacred.

\section{The consecration of objectified presence}

Before we address the centers and surroundings that reveal the being or agent of cultures, let us consider artifacts as works of art that, regardless of their scope, condense in invariable form - depending on the point of view the affections that constitute an ideal, whether lived or just desirable. In this sense we think that the significance of art, as enunciated by Roy Wagner (2017, p. 37), is very pertinent: "art is the magnifying glass under the sun of meaning. If this were not the case, if the transcendental achievements of art were not, at the same time, transcendental realizations of reality, it would not even be necessary to disqualify aesthetic constructions as mere devices or illusions". Even the perception of reality depends upon our own point of view.

These scattered artifacts highlight the multiple personalities of the agents that established the idea of religion in the context of Northern Israel cultural expressions. We have attestation dating from the Late Bronze Age of figurines representing male divinities in Hazor, Megiddo, Bet-shemesh (Bēt-Šemešs), Tēl Kinneret and Tell-Balātah (near to Nāblus). Both taurine figurines found 
in Betel and in Tel Dan, and also bronze icons found in Hazor probably date from the same period. A terracotta altar dating from the $10^{\text {th }}$ century BCE was found in Taanach (Tírinik), and is a prime example of cultic workmanship in Israelite lands. This altar is decorated with reliefs depicting naked female figures, lions and bas-reliefs. In the topmost part in one of its four sides, one can find a solar disk that is supported by animals; ${ }^{33}$ note that the solar disk became a dynastic symbol under the Pharaoh Amenhotep IV in the $14^{\text {th }}$ century BCE. ${ }^{34}$ This altar has been interpreted as showing the aniconic presence of Yhwh. Theodore J. Lewis (2016, p. 528 - 529) notes an agreement between ancient artisans and scribes in order to express the immaterial presence of Yhwh; however, we argue that the non recognition of the deity Yhwh in the altar's sun disk is supressing the symbolism of the icon itself. ${ }^{35}$ In an ivory object dug up at Nimrūd (Kalah/Kalhu) dating from the $8^{\text {th }}$ century BCE, one can see a winged disk, depicting at its top a female face - supposedly a sun goddess. This image matrix the Assyrians obtained may originate in the Egyptian depictions, copied in ancient Israel as alternatives to Yahwism, as demonstrated by the ivories in Megiddo. ${ }^{36}$

To the same extent of the divine presence in the holy place, the artifact is the pragmatic device that calls our attention in a highly symbolic environment. Indeed, apart from contrasting depictions, the most common artifact, the mașse $\bar{e} \bar{a} h$, was used as a divine symbol;" "Indeed, whereas most stone steles are anepigraphic, the abstract bull-headed warrior found at Bethsaida attests to the presence of either a lunar god with warrior features or a warrior god with lunar features" - notice this city lies in Galillee (LEWIS, 2016, p. 515).

In the Ancient Near East, statues, images or figurines ensure the divinity's royal presence in the māqôm; in the absence of a statue, it is substituted by a mașsēba consultations so that they fulfill ancient rules and are being accepted by the deity. But conditioning a god to a temple was not always a rule. In the temple of Anu in Uruk, his main temple starting in the $5^{\text {th }}$ century, many deities

\footnotetext{
33 Dug up a shrine bearing similar imagetic motives, e.g. MAZAR; PANITZ-CPHEN, 2007, p. $202-19$. See also Sigurður Hafpórsson (2006), and Lewis (2016).

34 On this, see SANTOS; WEBER, 2018.

35 In later significations of Yahweh we can find similar imagetical echoes, such as in Psalm 84.12a: K $\hat{\imath}$ šemeš ûmägèn Yhwh ("Because Yahweh [is] sun and shield").

36 Egyptian influence in the Levant is due to their regional protectorate since the 14 th century. Debate about the representations of the country on the Nile Valley has been established by many scholars. The ivory dug up at Nimrūd was mentioned by Izak Cornelius (2014, p. 150).

37 See 2 Kings 3: 2; 10: 26-27.
} 
were welcomed and their rituals practiced so as to ensure the presence of all in the feasts. Besides that, objectified presence went out in procession to be glimpsed by the crowd (CLANCIER, 2014). In this manner, the artifact, sacred icon, work of art - as a set of representations and oftentimes of identities - must be considered as entities when we address social agency, that is, interpersonal and aesthetical relations:

Les tenants de la seule 'expérience esthétique' pensent qu'une image perçue comme une source de pouvoir, d'exaltation ou de salut religieux n'est pas appréciée pour sa 'beauté', mais pour d'autres raisons. Or, selon moi, ces arguments sont erronés, pour deux raisons. Tout d'abord, je ne fais pas la différence entre l'émotion religieuse et l'émotion esthétique; il me semble que les amateurs d'art vouent tout autant un culte aux images, sauf qu'ils 'rationalisent' leur idolâtrie en l'appelant admiration esthétique" (GELL, 2010, p. 120).

The second aspect Alfred Gell highlights is that this so-called "aesthetic attitude" is just a result of scientific development. Therefore, let us note that it is impossible to dissociate an artifact's aesthetic form from its historical function - in order to construct belief, representation interacts with reality in a specific environment. Perceptually, it is in worship festivals that artifacts are treated the same way as other social agents, because they are present in the same spaces where they establish contacts. An artifact that represents deities is an arbitrary form to represent formless things. But it is not a deity's deformed image, because it is similar to a human form. Despite it all, all socio-identitary or witness-bearing theophorical representation is iconic. According to Gell (2010, p. 121), those "idols" regarded as "aniconic" because they are not shaped like an human body or another object are nevertheless icons. On the other hand, debate on the realism of cultic works of art is futile. Gell highlights that the artifact that "the space-temporal presence of the god", has always been a "representation" of a deity for a worhiper.

Despite the abundance of ivory and clay statues dating from the NeoAssyrian and Persian periods, artisanship was normally done on stone. Representations in personal objects and in sets of vessels and weaponry express society and the reasons that led to their elaboration. Those "gift and exchange objects appreciated, because of their reduced size and their precious quality, they favored the dissemination of images and techniques, conveying a part of their symbolic value and meaning" (CAUBET; GUBEL, 2014, p. 394). Because of this, works of art became the main diffusers of culture. They were technically associated to institutional rites before writing appeared. Those works of art show elaborate abstract geometric pictograms 
that were publically interpreted as expressions of communitarian identities. In the Late Bronze Age, starting in the $3^{\text {rd }}$ millennium BCE, images relate to ideological orientations in the performance of political and religious rituals and ceremonies.

Royal iconography is intended for the "king's men". Terracotta scenes depict them in official activities or begging the protection of a deity; Egyptian figurative arts strongly influenced artistic themes and subjects during the second millennium BCE, especially art produced in the Mediterranean Coast. In the end of Late Bronze, at first palace economy, and then ancestral or politically ideological iconography will be preeminent in the production of figurines and amulets until the Persian Achaemenid period. In the southern Levant, we notice changes with the emergence of Arameans Syrian artifacts influenced by Hittite and Mitanian production. Those artifacts evidence cultural interactions in the region, as well as circulation of supra-regional traditions.

Finally, from the Iron Age, in the civilizing processes of the southern Levant, in the realms of religion and politics, they will give preference to "papyrus as the support of cursive and alphabetic linear scriptures" (CAUBET; GUBEL, 2014, p. 401), highlighting a new scenographic invention. Demographical dynamism increased later on to contain pressures from the Neo Assyrian Empire until the fall of Sidon $(S i-d u-n a)$ (c. 685) and the isolation of Tyre in the following decades. Products were renamed and gained new uses, whose reflexes can be noticed in Classical Antiquity.

We now present two issues with commercial background: Phoenicians adapted techniques from other people, and, later on, transmitted them to their neighbors in the northern Levant and Transjordan (CAUBET; GUBEL, 2014, p. 394). We should not downplay two important cultural transformations that started in the Bronze Age. First, palaces became an international political presence. Long term economical changes that started with the sedentarization of vast social groups - that show their fullest extent in the great hegemonic kingdoms. In other words, the transformations undergone by two domains that shape societies - politics and economics - led social groups in Northern Transjordan to contact the Northern Levant. Gilead was a propellant of culture.

Second, artifacts or works of art are one and the same as magical points of contact with a deity. We can associate this shift in perspective to the veracity of the deity itself: its presence and powers are not just abstractions or mental figurations. When an event is associated to an object - for instance, the reaping of a fruit makes it fertile - the object's nature is theoretically associated to fertility. Another example comes from the māori (New Zealand natives). The mauri fertility stones present many shapes. They are aniconical, 
but stone sculptures representing open mouths that favor potato growth sit next to offerings of fresh fruit! The pedagogical aspect lies in the appreciation of the act of feeding (GELL, 2010, p. 134-135), in a society that rejects centralization of power.

If there is any conceptual conflict, it can be measured by the distinction between animated being - that lives as an agent of royalty or divination - and inanimate being which are non-living, figurative art. There is nothing to confuse both types of being, but agents in the religious field appear in those different forms -animated beings are conscious of their biological condition in relation to their artifacts' natural condition. But deities have been represented both ways. A worshipper that prostrates before a cultic object believes: "one way or another believes that the stone in question, even if it is not living, sees and understands how the believer thinks and reacts like him, and also has the power to anticipate and acclimate actions" (GELL, 2010, p. 151). We can restrict the difference to the notion of intentionality attributed to ordinary human beings. We note that debates about the intellection of artifacts, such as works of art and figurative indications, have observed beliefs and practices that are "apparently irrational" in parallel to the qualities of social agents - whom are depositaries of agency and possess sensitivity.

About that, in cultural contexts where artifacts are admittedly counterintuitive, at least sometimes they are assumed to have unusual, concealed properties: ${ }^{38}$

Pour convertir (abstraitement) un objet inanimé en une quasi-personne, nous avons le choix entre deux grandes stratégies. La première consiste à animer l'idole en lui attribuant un rôle d'autre social. La seconde consiste à lui fournir un homoncule, ou de l'espace pour un homoncule, ou à la transformer en un homoncule à l'intérieur d'une plus grande entité" (GELL, 2010, p. 164).

There lies the genius of Ancient mobile shrines - adding innate gender diversity and hybridization. This enabled the survival and contemporary significance of small figurines instead of murals or large statues - perhaps due to ease of transportation. They show some stylistic principles (the form, the model) that are specific to a place. As individual projections in a society founded on kinship lines, our perceptual challenge is to identify in those religious artifacts evidences of principles of progeny, pacts and gift-giving. We find one of those principles in the covenant gestures between Jehu and

38 So affirms Alfred Gell (2010, see especially p. 150-155). 
Jonadab (Yəhônādāb ben Rēkāa), ${ }^{39}$ a public pact for the extinction of Baal worship in Israel. ${ }^{40}$ We have a limestone monument dating from the same period found in the throne room of Shalmaneser III in Nimrūd (SCHROER; STAUBLI, 2003, p. 196). It depicts him establishing a covenant to another king with a handshake.

By the reasons explained above, conceptions of god in Ancient Israel were in accordance to the Levantine cosmological systems - even though, to a certain degree, its peculiar characters were eventually shaped as dispersed parts of the same corpus. It was important that the deity remained accessible, to allow cult as a familial event even in public spaces. Maybe objects and utensils projected the idea of Yahweh beyond human reach, that is, with no human-shaped image even if in prefixed spaces. Ironically, Othmar Keel's allusion (2007, p. 171) that "nothing in the world - neither king nor animal (bull) nor star constellation - can adequately embody Yahweh" leads him to immediately acknowledge that "this does not mean, however, that all conceptions of Yahweh are illegitimate". So, iconographical intellection has always faced intrigue, even with the Israelite prophets from the VIII and VII centuries BCE. The expression of divine experience and Yahweh's direct accessibility made a relation between deity and its people possible.

To affirm it presence also meant the use of a mask or a cloud ('anann). The evidence extant "exodus from Egypt" narratives in Exodus and Numbers, dating from the VIII-VI centuries BCE, in relation to Yahweh may be placed in the context of "runaway Aramites" that existed previously in the Late Bronze Ugaritic myths. Another presentification is via a "column" ('ammüd) that, according to George E. Mendenhall (1976, p. 58), is an Hurrian tradition as Šerriš, a pillar of cloud associated to daytime, and Hurriš, a pillar of fire associated to nighttime. We also have evidence of that among Egyptian and Assyrian deities, as well as Anatolian winged disks exhibiting two columns.

It is commonly said that an Israelite did not distinguish particular areas of action by Yahweh (KEEL, 2007, p. 171). However, this is invalid - because it disregards the mnemés of those hierophanies that constituted sacred spaces. Besides, we disagree with Keel's indication of a mental concept - he says there is no way to gauge Yahweh's specificity nor tradition emphasis (the "rock", for instance), due to familial symbology. Statue making is closely tied

39 See 2 Kings 10: 15-16.

40 We disagree with Schroer and Staubli's claim that Jehu "mingles with Jonadab in the fight against the Ahab dynasty and the Baal cult". The pact is for the extermination of Baal worshippers, and, therefore, of its cult. We offer the following reasons: Jehoram, king of Israel (2 Kings 9: 24), Jezebel (9: 33), the king's sons (10: 7) and all bêt 'Ah' $\bar{a} b$, survivors in Jezreel (10: 11) and Samaria (10: 14) were assassinated before Jehu e Jonadab formed a pact (10: 15). The slaughter Jehu and Jonadab participate in Samaria targets the worship (10: 25) and probably a city-coutryside coalition for governance. 
to human perception of divine action in historical events, especially in those in which favorable outcomes would be admittedly impossible.

The occurrence of formulas about events of life and death evidences a deity's sovereignty and divine control. We have evidence dating from the monarchic period that show Yahweh's pictographic involvement with war - despite many who consider this a later development. He is depicted as a warrior and destroyer, with attributes like those of Rešep in Egypt. He bears weaponry that had been incorporated to Rešep's icons in the temples in the Mediterranean cities of Byblos (Gu-ub-la) and Haddu in Aleppo. His weaponry includes the spear $(r m h)$, shield (shrh, "portable shield"; $m g n$, "shield"; $s n h$, "tower shield"), arrow (hs $)$, javelin (hnyt) and axe (sagōr). In contexts of translation, during periods of conflict, traditions of social revolution are incorporated into the god of reference among the many designations tied to that deity. Even though people knew weapons carried by the king's garrison, Yahweh received the same warrior attributes and weaponry of the deities El (Canaanite), Haddu (halabite) and Nimrūd (Mesopotamian). Mutation is the last stage - then a deity's nationalization occurs.

Works of art undego the same mutation. Amihai Mazar (2008) dug up at Tèl Rehōv an object sculpted from pink-yellowish ivory that serves as an example of aesthetic mutation. It is still difficult to pinpoint which animal it is, but its measurements are: 8.5 centimeters high, 4.4 centimeters wide and 3.5 centimeters maximum length on the underside, its artistic model is interesting. The statuette's arms were sculpted separately and then joined to the body. It depicts in three dimensions the enthronement of a humanlike figure. The throne is almost entirely preserved. The quality of this work connects it to the cities of Megiddo and Samaria. Mazar considers that the statue has ties to works of art from $9^{\text {th }}$ century BCE Samaria, but notes its similarity to other enthronement sculptures from the Ancient Near East during the second Millennium BCE. It is particularly similar to Gudea ( $c$. 2140-2120 [2150-2125]), a king from the second Lagaš ${ }^{41}$ dynasty - whose statute dedicated to the deity Ninğišzida (Sumerian: ${ }^{\mathrm{d}}$ nin- $\breve{g} i s$ - $\{i d-d a$ ) dates to around 2120 BCE [2090 BCE].

In Syria, the Middle Bronze statue of king Ebla ('Íblä) and the Late Bronze I statue of king Idrimi of Alalah are exemplary. They were sculpted by compositing pieces with ivory and techniques imported from Phoenicia.

41 It is unclear wheter Mazar uses Gudea as an example to affirm a second Millennium model; however, the Lagaš king dates from the third Millennium - the last long duration period in Ancient Bronze. On the other hand, the date in the Musée du Louvre (Paris - where the work is kept) catalog differs from that offered by the website of The Metropolitan Museum of Art (New York). Thus we offer both dates. 
Some think this was a work from Damascus, by a sculptor affiliated to some southern Syria school - the artist created "an enthroned governor being approached by his queen". Mazar affirms this is peculiar to the period of Omride Dinasty prosperity. The ecstatic aspect of northern divinatory rituals may have influenced the artisan.

Ivories from Samaria differ from those found in Phoenicia, in the south and in northern Syria - where most of the production occurred. Ann E. Killebrew (2014, p. 738) mentions around one thousand fragments, whereas Claudia E. Suter (2011, p. 220-22) - that also studied those materials - says she found approximately twelve thousand pieces. Among those, one can count "luxuriously inlaid furniture, precious treasure chests, cosmetic boxes, fly whisks, and goblet stands"; however, those objects were not dug up exactly where they were used. This does not conceal that they were used for things other than divination and auguries. So, Suter proposes that these images reflect the identities of the Levantine ruling classes, depicting the political ideology that they identified with among themselves. Even if they are fewer than ornaments and at the symbolic level, sculptures "depicting animal combat scenes associated with the king's role as hunter and protector against the chaotic forces of nature" from Late Bronze that were dug up at southern Syria, establish artistic dialogues to ancient Mesopotamian tradition exemplars (SUTER, 2011, p. 228). Combat against the forces of chaos - chaotic precisely because they escape human control - for protection, prosperity and divine favor must be ascribed to religious environment because of context.

\section{Conclusion}

Our objective in this research was to present the processes of elaboration of the divine presence in ancient Israel, that is, religious presentness. This presence becomes noticeable through bodily aesthetics, objectified. That is why it goes beyond the boundaries represented by a decorative artifact when it becomes an agent of culture. Theoretically, the idea of the presence of the divinity is linked to the sacred space, which gains meaning due to the cult of the divinity and its identification with the place. Around this, the traditions of belonging, architecture, cultic paraphernalia and legitimate political events are invented. Despite the researched contexts being located in the Levant, it was demonstrated, despite the historiographical complexity, that the Israeli narratives depended on the Aramean languages. We understand that this was proven by demonstrating that the conceptions of God in ancient Israel have as 
matrix sources, in their elaboration processes, the works of art - the art is the depository of agentivity and possesses sensitivity.

In fact, works of art apprehend divine beauty during ritual performance, in that an artifact exists entirely for its worshippers - that is, "a subject is defined only by his relation to the object", ${ }^{42}$ a symbolic action that turns art into an event articulated by the divinatory sense it emits. Elaboration of this new creation transcends any utilitarian procedures in the guise of mnème manipulation in temple architecture. This allows us to affirm along with João Manuel Duque (2018, p. 19) that "rituality is a proper, pragmatic and corporeal mode of personal and collective appropriation of this memory", because, in our opinion, the deity creates itself in ritualistic interaction, conducting cultic action and performance.

\section{Referências bibliográficas}

ALBERTZ, Rainer. Historia de la religión de Israel en tiempos del Antiguo Testamento. Vol. 1: De los comienzos hasta el final de la monarquía. Traducción de Dionisio Mínguez. Madrid: Editorial Trotta, 1999.

ALBERT, Rainer. Methodological reflections. In: ALBERTZ, Rainer; RÜDIGER, Schmitt. Family and housebold religion in ancient Israel and the Levant. Winona Lake, IN: Eisenbrauns, 2012, p. 21-56.

AMZALLAG, Nissim. Yahweh, the canaanite God of metallurgy? JSOT, v. 33, p. 387-404, 2009.

BECKMAN, Gary. How religion was done. In: SNELL, Daniel C. (ed.). A Companion to the Ancient Near East. Malden, MA: Blackwell, 2007, p. 366-376.

BOTTÉRO, Jean. La religión más antigua: Mesopotamia. Traducción de María Tabuyo y Augustín López. Madrid: Editorial Trotta, 2001.

CAUBET, Annie; GUBEL, Éric. Art figuré miniature. In: BORDREUIL, Pierre; BRIQUEL-CHATONNET, Françoise; MICHEL, Cécile (dir.). Les débuts de l'Histoire: civilisations et cultures du Proche-Orient ancien. Nouvelle édition revue et augmentée. Paris: Éditions Khéops, 2014, p. 394-402.

CAZELLES, Henri. História politica de Israel: desde as origens até Alexandre Magno.

Tradução de Cácio Gomes. São Paulo: Paulinas, 1986.

CLANCIER, Philippe. Le monde des temples. In: BORDREUIL, Pierre; BRIQUEL-

CHATONNET, Françoise; MICHEL, Cécile (dir.). Les débuts de l'Histoire: civilisations et cultures du Proche-Orient ancien. Nouvelle édition revue et augmentée. Paris: Éditions Khéops, 2014, p. 434-438.

COGAN, Mordechai; TADMOR, Hayim. II Kings: a new translation with introduction and commentary. AB 11. Garden City, NY: Doubleday, 1988.

42 João Manuel Duque refers to art as an event (2018, p. 13). 
CORNELIUS, Izak. 2014. "Trading Religions" and "Visible Religion" in the ancient Near East. In: WICK, Peter; RABENS, Volker (eds.). Religions and trade: religious formation, transformation and cross-cultural exchange between East and West. Leiden: E. J. Brill, 2014, p. 141-165.

DEVER, William G. Archaeology and the question of sources in Kings. In: LEMAIRE, André; HALPERN, Baruch (eds.). The Books of Kings: sources, composition, historiography, and reception. Atlanta, GA: SBL Press, 2010, p. 517-538.

DUQUE, João Manuel. Ritualidade da arte: performatividade da memória. Revista de Estudos da Religião, v. 18, n. 1, p. 11-30, 2018.

ELLIGER, Karl; RUDOLPH, Wilhelm. Biblia Hebraica Stuttgartensia. 5. aufl. Stuttgart: Deutsche Bibelgesellschaft, 1997.

FOSTER, Benjamin R. Transmission of knowledge. In: SNELL, Daniel C. (ed.). $A$ Companion to the Ancient Near East. Malden, MA: Blackwell Publishing, 2007, p. 261-268.

GELL, Alfred. L'art et ses agentes: une théorie anthropologique. Traduit par Sophie Renaut et Olivier Renaut. Paris: Les Presses du Réel, 2010.

HAFDÓRSSON, Sigurður. Chapter Six: archaeological sources. Excavations in Northern Palestine - Tall al-Qāộ̄ (Tel Dan). In: A passing power: an examination of the sources for the history of Aram-Damascus in the second half of the Ninth Century B.C. Stockholm: Almqvist \& Wiksell International, 2006, p. 222-229.

HUTTON, Jeremy M. Southern, Northern and Transjordanian perspectives. In: STAVRAKOPOULOU, Francesca; BARTON, John (eds.). Religious diversity in ancient Israel and Judah. London: T\&T Clark, 2018 [2010], p. 149-174.

KEEL, Othmar. La iconografía del antiguo Oriente y el Antiguo Testamento. Traducción de Andrés Piquer. Madrid: Editorial Trotta, 2007.

KILLEBREW, Ann E. Israel during the Iron Age II Period. In: STEINER, Margreet L.; KILLEBREW, Ann E. (eds.). The Oxford Handbook of the Archaeology of the Levant: $c$. 8000-332 BCE. Oxford: Oxford University Press, 2014, p. 730-742.

LEMAIRE, André. Inscriptions hébräques. Tome 1: Les ostraca. Littératures Anciennes du Proche-Orient. Paris: Éditions du Cerf, 1977.

LEWIS, Theodore J. Art and Iconography: Representing Yahwistic Divinity.” In: NIDITCH, Susan (ed.). The Wiley Blackwell Companion to Ancient Israel. Malden, MA: Blackwell Publishing, 2016, p. 510-533.

LIVERANI, Mario. Antico Oriente: storia, società, economia. Roma; Bari: Editori Laterza, 2009.

MARGUERON, Jean-Claude. Entre profane et sacré: Y a-t-il des degrés dans la sacralisation de l'espace Mésopotamien (IV ${ }^{\mathrm{e}}-\mathrm{I}^{\text {er }}$ Millénaire av. J.-C.)? In: LAFOND, Yves; MICHEL, Vincent (dir.). Espaces sacrés dans la Méditerranée antique. Rennes: Presses Universitaires de Rennes, 2016, p. 15-56.

MAZAR, Amihai. The divided monarchy: comments on some archaeological issues. In: SCHMIDT, Brian B. (ed.). The quest for the historical Israel: debating archaeology and the history of early Israel. Leiden: E. J. Brill, 2007, p. 159-179.

MAZAR, Amihai. An ivory statuette depicting an enthroned figure from Tel Re $\square$ ov. In: BICKEL, Susanne; SCHROER, Silvia; SCHURTE, René; UEHLINGER, Christoph (eds.). Bilder als Quellen Images as sources. Studies on ancient Near Eastern artefacts and the 
Bible inspired by the Work of Othmar Keel. OBO. Fribourg; Göttingen: Academic Press Fribourg; Vandenhoeck \& Ruprecht Verlag, 2008, p. 101-110.

MAZAR, Amihai; PANITZ-COHEN, Nava. It is the Land of Honey: beekeeping at Tel Rehov. NEA, v. 70, n. 4, p. 202-219, 2007.

MENDENHALL, George E. The Tenth Generation: the origins of the biblical tradition. Baltimore; London: The Johns Hopkins University Press, 1976.

MEYERS, Carol. Household religion. In: STAVRAKOPOULOU, Francesca; BARTON, John (eds.). Religious diversity in ancient Israel and Judah. London: T\&T Clark, 2018 [2010], p. 118-134.

NIEHR, Herbert. "Israelite" religion and "Canaanite" religion. In: STAVRAKOPOULOU, Francesca; BARTON, John (eds.). Religious diversity in ancient Israel and Judah. London: T\&T Clark, 2018 [2010], p. 23-36.

NOGUEIRA, Paulo Augusto de Souza. Religião como texto: contribuições da semiótica da cultura. In: NOGUEIRA, Paulo Augusto de Souza (org.). Linguagens da religião: desafios, métodos e conceitos centrais. São Paulo: Paulinas, 2012, p. 13-30.

OLMO LETE, Gregorio del (Edición y traducción). Mitos, leyendas y rituals de los semitas Occidentales. Madrid; Barcelona: Editorial Trotta; Edicions de la Universitat de Barcelona, 1988.

PATERA, Ioanna. La consecration de l'espace: action rituelle, investissement spatial et visibilité. In: LAFOND, Yves; MICHEL, Vincent (dir.). Espaces sacrés dans la Méditerranée antique. Rennes: Presses Universitaires de Rennes, 2016, p. 57-67.

ROCHE-HAWLEY, Carole. La Reconstruction du Temple de Ba'lu à Ougarit au XIII ${ }^{e}$ Siècle av. J.-C.: Entre Mythe et Réalité. In: LAFOND, Yves; MICHEL, Vincent (dir.). Espaces sacrés dans la Méditerranée antique. Rennes: Presses Universitaires de Rennes, 2016, p. 83-93.

RÖMER, Thomas. A origem de Javé: o Deus de Israel e seu Nome. Trad. Margarida Maria Cichelli Oliva. São Paulo: Paulus, 2017a.

RÖMER, Thomas. L'Énigme de 'Ashtar-Kemosh dans la Stèle de Mesha. In:

FINKELSTEIN, Israel; ROBIN, Christian; RÖMER, Thomas (eds.). Alphabets, texts and artifacts in the ancient Near East. Studies presented to Benjamin Sass. Paris: Van Dieren Éditeur, 2017b, p. 385-394.

RUSSELL, Stephen C. Religious Space and Structures. In: BARTON, John (ed.). The Hebrew Bible: a critical companion. Princeton, NJ: Princeton University Press, 2016, p. 356-377. SANTOS, João Batista Ribeiro. A proskynesis do rei israelita Yĕbû ao rei assírio Šulmānuašaridu no "Obelisco Negro": uma apresentação contextual do relevo. Caminhando, São Bernardo do Campo, v. 19, n. 2, p. 85-99, 2014. [10.15603/2176-3828/caminhando. v19n2p85-99]

SANTOS, João Batista Ribeiro; WEBER, Fabíola. Na periferia dos impérios: historiografia contextual das cartas do governante Bir-ia-wa-za, de Di-maš-qa, para o grande rei Amenhotep IV, do Mi-iṣ-ri. Caminhando, São Bernardo do Campo, v. 23, n. 1, p. 28-56, 2018. [http://dx.doi.org/10.15603/2176-3828/caminhando.v23n1p29-56]

SCHROER, Silvia; STAUBLI, Thomas. Simbolismo do corpo na Bíblia. Trad. Paulo Ferreira Valério. São Paulo: Paulinas, 2003. 
SILVA, Cássio Murilo Dias da. Aquele que manda a chuva sobre a face da terra. São Paulo: Paulinas, 2006.

SMITH, Mark S. God in translation: deities in cross-cultural discourse in the Biblical World. Grand Rapids, MI: Eerdmans, 2010.

SOUTHWOOD, Katherine. The social and cultural history of ancient Israel. In: BARTON, John (ed.). The Hebrew Bible: a critical companion. Princeton, NJ: Princeton University Press, 2016, p. 54-85.

SPERLING, S. David. Monotheism and Ancient Israelite Religion. In: SNELL, Daniel C. (ed.). A Companion to the Ancient Near East. Malden, MA: Blackwell Publishing, 2007, p. 430-442.

SUTER, Claudia E. Images, tradition, and meaning: the Samaria and other Levantine ivories of the Iron Age. In: FRAME, Grant et al. (eds.). A common cultural heritage. Studies on Mesopotamia and the Biblical World in Honor of Barry L. Eichler. Bethesda: CDL Press, 2011, p. 219-241.

TERRA, João Evangelista Martins. O Deus dos Semitas. São Paulo: Loyola, 2015.

WAGNER, Roy. Símbolos que Representam a Si Mesmos. Tradução de Priscila Santos da Costa. São Paulo: Editora da Universidade Estadual Paulista, 2017.

WAZANA, Nili. Ahaz and the altar from Damascus (2 Kings 16:10-16): literary, theological, and historical-political considerations. In: OMER, Sergi; OEMING, Manfred; HULSTER, Izaak J. de (eds.). In search for Aram and Israel: politics, culture, and identity. Orientalische Religionen in der Antike. Band 20. Tübingen: Mohr Siebeck, 2016, p. 379-399.

Submetido em: 28-8-2020

Aceito em: 21-9-2020 